\title{
THE ACCESSIBILITY ANALYSIS OF COVID-19 REFERRAL HOSPITALS TO THE LOCATION OF FUNDAMENTAL STUDENT
}

\author{
Bella Theo Tomi Pamungkas ${ }^{1}$, Arfita Rahmawati ${ }^{2}$ \\ ${ }^{1,2}$ Departement Geography Education, Nusa Cendana University \\ Email: bella.pamungkas@staf.undana.ac.id
}

\begin{abstract}
The Covid-19 pandemic that occurred in all parts of the world has had an impact on the various sectors. Not only in the economic sector but also in the educational sector. Until Month June Year 2020, the Indonesian government had carried out a new-normal policy. The purpose of the study was to analyze the affordability of the Covid-19 referral hospital to the position of students during the new-normal era. The affordability could be observed by the distance traveled by students to the nearest Covid-19 referral hospital. This study used the OD matrix layer from ArcMap 10.3. The sample used in this study was 87 students with 11 Covid-19 referral hospitals in East Nusa Tenggara Province. Based on the research results in the form of maps produced, showed that from 87 students observed, only 59 or $67.82 \%$ could reach the Covid-19 referral hospitals. Meanwhile, the other 28 students or $32.18 \%$ couldn't be reached by the hospitals. The amount of students observed, located less than $15 \mathrm{~km}$ from the Covid-19 referral hospitals were 35 or $40.22 \%$ from the total of 87 students. The hospital which students refer to based on their location was the WZ. Yohanes hospital.
\end{abstract}

Keywords: Covid-19; OD Matrix Layers; Referral Hospital

\section{A. INTRODUCTION}

Covid-19 is a problem experienced by most countries in the world. Corona virus disease 19 (Covid-19) has developed into a catastrophic pandemic with over millions of confirmed cases worldwide (Glass et al., 2020). Between January and April 2020, the epidemic turned into a global pandemic from its origin center in Wuhan, China, reaching most countries around the world (Dryhurst et al., 2020). Covid-19 pandemic has spread fast almost all countries in the world including Indonesia (Syuhada et al., 2021). The cases Covid-19 in Indonesia until the date of 30
September 2020 confirmed were 291,000 cases, with a mortality rate of 10,856 cases (BNPB, 2020). This shows the mortality rate in Covid-19 cases in Indonesia is $3.73 \%$. East Nusa Tenggara Province, one of the provinces in Indonesia, impacted from the Covid-19 pandemic. Until the date of September 30th, Year 2020, there were 424 cases of Covid-19 in the Province of East Nusa Tenggara. The confirmed Covid-19 cases in each district in the Province of East Nusa Tenggara has difference in amount. This amount can be seen in the following table. 
Table 1. Number of Covid-19 Cases in Each Regency in East Nusa Tenggara Province Until September 30, 2020

\begin{tabular}{c|c}
\hline District & Cases \\
\hline Ende & 212 \\
Kota Kupang & 160 \\
Manggarai Barat & 122 \\
Sikka & 102 \\
Manggarai & 54 \\
Sumba Barat & 52 \\
Sumba Timur & 42 \\
Kabupaten Kupang & 30 \\
Flores Timor & 22 \\
Nagekeo & 18 \\
Timor Tengah Selatan & 18 \\
Sumba Barat Daya & 10 \\
Rote Ndao & 4 \\
Alor, Lembata, Malaka, Manggarai Timur, Sumba & 2 \\
Tengah, dan Timor Tengah Utara & \\
\hline
\end{tabular}

Source: (Satgas Covid-19 NTT, 2020)

Based on table 1, the district with the highest Covid-19 cases until September 30th, Year 2020, in East Nusa Tenggara Province is Ende Regency with 212 cases, and then followed by Kota Kupang with 160 cases. Meanwhile, districts with the lowest number of the case observed in Alor District, Lembata District, Malaka District, East Manggarai District, Central Sumba District, and North Central Timor District with 2 cases each respectively.

Covid-19 disease in the worst cases leads to severe manifestations such as acute respiratory distress syndrome (ARDS), multi-organ failure, and mortality because manifestations can be caused by a hyperactive and misguided immune response (Maucourant et al., 2020). Symptoms such as fever or cough, and signs such as oxygen saturation or lung auscultation findings, are the first diagnostic information regarding this disease, further diagnostic testing used from this information (Emperador et al., 2020). Further testing used a swab test to find out viral RNA using a sample usually obtained from the respiratory tract with a nasopharyngeal swab (Watson, n.d.).

The Covid-19 pandemic has also rocked the education sector, and this fear is likely to reverberate across the education sector globally by forcing many schools and colleges to temporarily closed (Dhawan, 2020). As a step to protect school residents from exposure to Covid-19, various regions have established learning from home policies (Arifa, 2020). It also causes Nusa Cendana University rectors to issue a policy to implement online learning 
activities. Online learning carried out by students, currently causes many students to return to their respective home. The high level of confirmed cases Covid-19 in the Province of East Nusa Tenggara with the level of different cases in each country provides its anxiety for students. Meanwhile, the Covid-19 referral hospital available in East Nusa Tenggara Province is only 11 hospitals. The level of coverage of the Covid-19 referral hospital that has been determined by the government certainly helps students who are return to their respective hometowns. However, the geographic condition of East Nusa Tenggara Province, which is mostly in the form of islands, certainly poses a challenge to the affordability of the hospitals to the current student positions. This study aims to determine the affordability of the Covid-19 referral hospital to student locations and to observe the mileage of students to the location of the nearest hospital.

\section{B. MATERIALS AND METHODS}

This research is descriptive quantitative research. The research is located in East Nusa Tenggara Province. The population used is the Geography Education Form 3A 2019 data with a total of 671 students. For sampling, the Slovin formula (Purwanto; et al., 2019) was used:

$$
n=\frac{n}{1+\left(n x e^{2}\right)}
$$

Based on the calculation, the amount sample acquired was 87 students out of 671 in total. Data were collected in this study through a questionnaire posted online by using Kobotoolbox. The researcher sent a link contains questionnaire to each respondent to be filled out as a feed back to the questionnaire. The OD Matrix Layer analysis was used to analyze the parameters which had already collected. OD Matrix is the core data and prerequisite for traffic planning and management ( $\mathrm{Lu}$ et al., 2016). The OD method is used for cases where the supply pattern in terms of velocity and current is available (Krishnakumari et al., 2020). The parameters used in conducting the OD Matrix Layer were the main road, the Covid-19 referral hospital, and the location of the student. To identify the main obstacle to hospital affordability and its solution, questionnaires were distributed among students.

\section{RESULTS AND DISCUSSION}

Before doing the OD Matrix Layer analysis, it is necessary to know the location of the student, the location of the referral hospital, and the road network. 


\section{Student Location}

The location is known when students filled out the questionnaire on the link that had already given by the researchers, thus known as the distribution location.
Furthermore, cluster analysis was used to determine the distribution pattern. The distribution of the student locations presented in the following map:

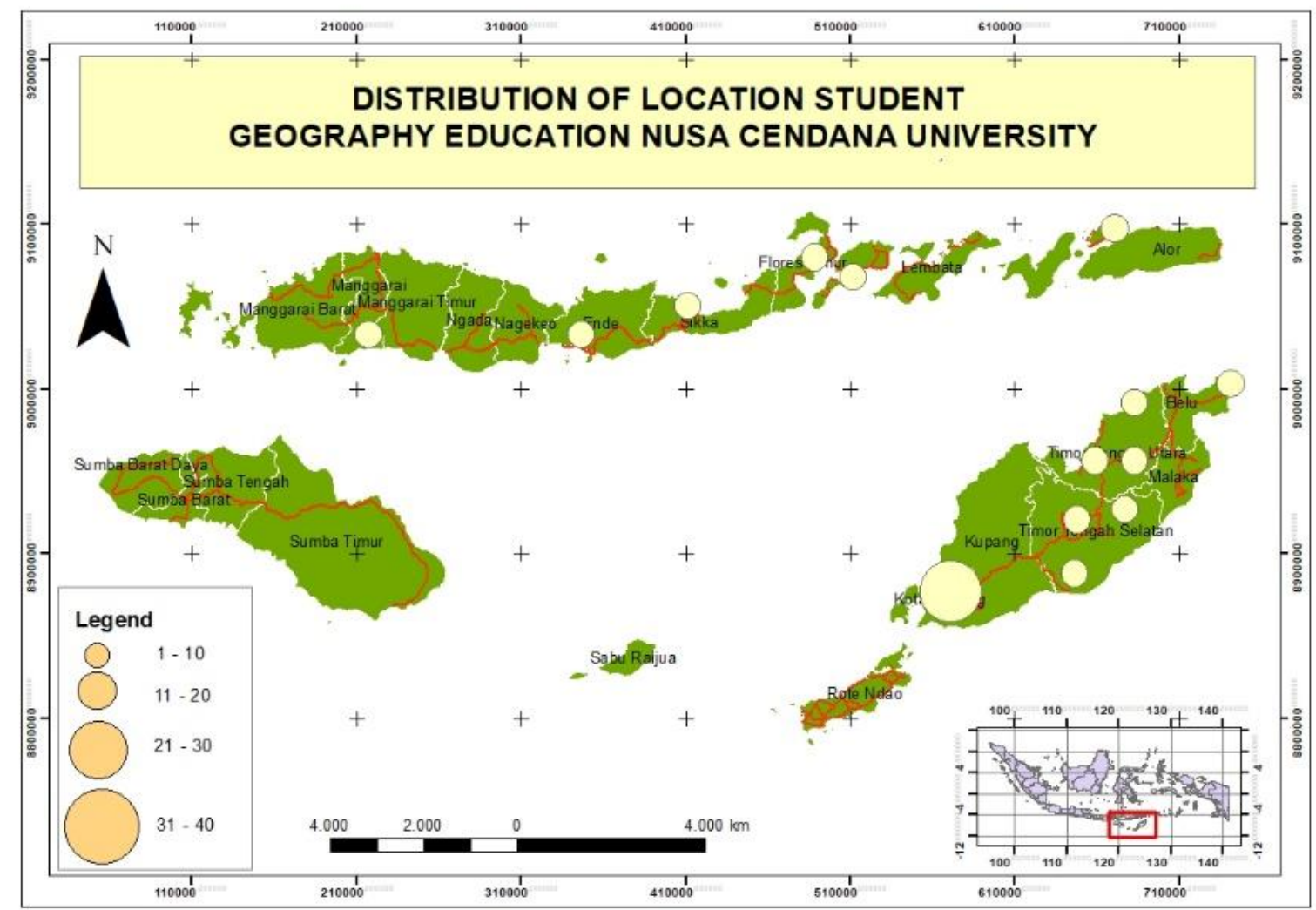

Figure 1. Distribution of Location Students

Figure 1 showed that most students were located in Kupang City and Kupang Regency. Some other students scattered in other districts.

\section{The Covid-19 Referral Hospital}

List of names and addresses of the referral hospitals were obtained from the
Covid-19 Task Force in East Nusa Tenggara Province. Based on the data from the East Nusa Tenggara Province Covid-19 Task Force in 2020, it is known that there are 11 Covid-19 referral hospitals in East Nusa Tenggara Province. The list of names of referral hospitals are shown below: 
Table 2. List Name and Adress Covid-19 Referral Hospital in East Nusa Tenggara Province

\begin{tabular}{|c|c|c|}
\hline No & Name & Adress \\
\hline 1 & RSUD WZ. Yohanes Kupang & Jl. Moch Hatta No.19, Oetete, Kec. Oebobo, Kota Kupang \\
\hline 2 & RSUD T.C. Hillers Maumere & $\begin{array}{l}\text { Jl. Wairklau No.1, 86113, Kota Uneng, Alok, Kabupaten } \\
\text { Sikka }\end{array}$ \\
\hline 3 & RSUD Komodo, Labuan Bajo & $\begin{array}{l}\text { Jl. Raya Labuan Bajo-Ruteng, Golo Bilas, Komodo, } \\
\text { Kabupaten Manggarai Barat }\end{array}$ \\
\hline 4 & RSUD Gabriel Manek, Belu & Tenukiik, Berdao, Atambua Bar., Kabupaten Belu \\
\hline 5 & RSUD Alor & $\begin{array}{l}\text { Jl. Dr Sutomo No } 8 \text { Kalabahi Teluk Mutiara Alor, Kalabahi } \\
\text { Kota, Teluk Mutiara, Alor Regency }\end{array}$ \\
\hline 6 & RSUD Ba'a Rote Ndao & Jl. BA'A Busalangga, Mokdale, Lobalain, Kabupaten Rote \\
\hline 7 & RSUD Sabu Raijua & Menia, Sabu Bar., Kabupaten Sabu Raijua \\
\hline 8 & RSUD Lewoleba, Lembata & Lewoleba Tim., Nubatukan, Kabupaten Lembata \\
\hline 9 & RSUD Ende & $\begin{array}{l}\text { Jalan Prof. Dr. W.Z Yohanes, Kel. Paupire, Ende Tengah, } \\
\text { Kabupaten Ende }\end{array}$ \\
\hline 10 & RSUD Umbu Rara Meha Waingapu & $\begin{array}{l}\text { Jl. Ikan Kombong, Kambajawa, Kota Waingapu, Kabupaten } \\
\text { Sumba Timur }\end{array}$ \\
\hline 11 & RSUD Waikabubak Sumba Barat & Dira Tana,, Soba Wawi, Loli, Kabupaten Sumba Barat \\
\hline
\end{tabular}

Source: Satgas Covid-19 East Nusa Tenggara Province, 2020

In Table 2, from 22 districts in East

Nusa Tenggara, there were only 11 Covid-

19 referral hospitals in the province of East

Nusa Tenggara. From this data, the coordinate then could be recorded. After made in the form of a map, the results are as follows:

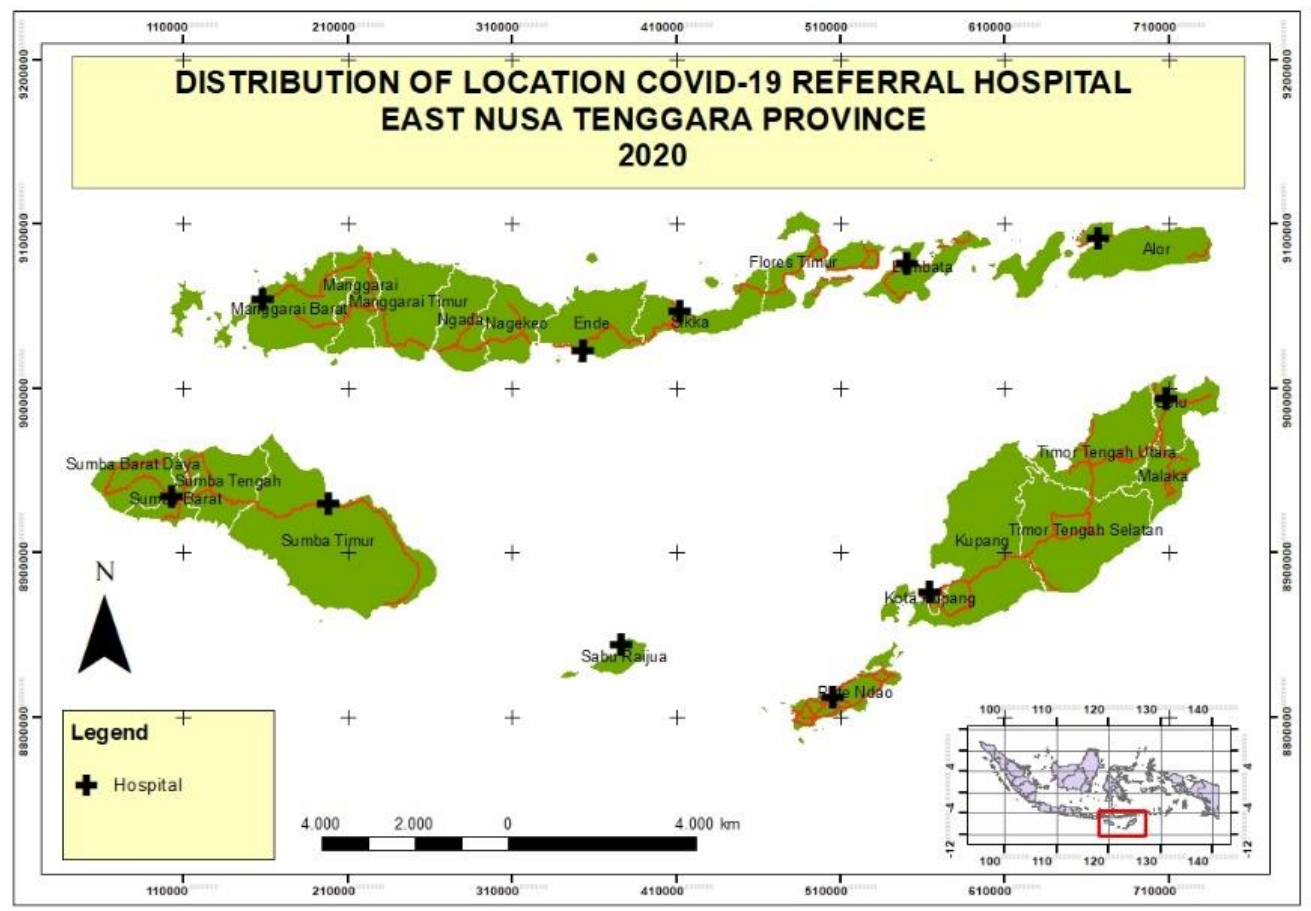

Figure 2. Distribution of Location for Covid-19 Referral Hospital 
Figure 2 showed the known location of the Covid-19 referral hospital which located only in Sikka District, Kupang City, West Manggarai District, Belu District, Alor District, Rote District, Sabu Raijua District, Lembata District, Ende District, East Sumba District, and West Sumba District. Meanwhile, 11 other districts in East Nusa Tenggara Province did not have Covid-19 referral hospitals.

\section{Student Coverage of Covid-19 Referral Hospitals}

To find out the affordability of the students to the nearest hospital OD Matrix Layer analysis was used. So that if any students suffers from Covid-19, the students could handle it immediately. First of all, it is necessary to know the road network in East Nusa Tenggara Province. The road network map in East Nusa Tenggara Province was obtained from Google Earth 2020 then carried out by delineation. The following is a road network map of the location of Covid-19 referral students and hospitals:

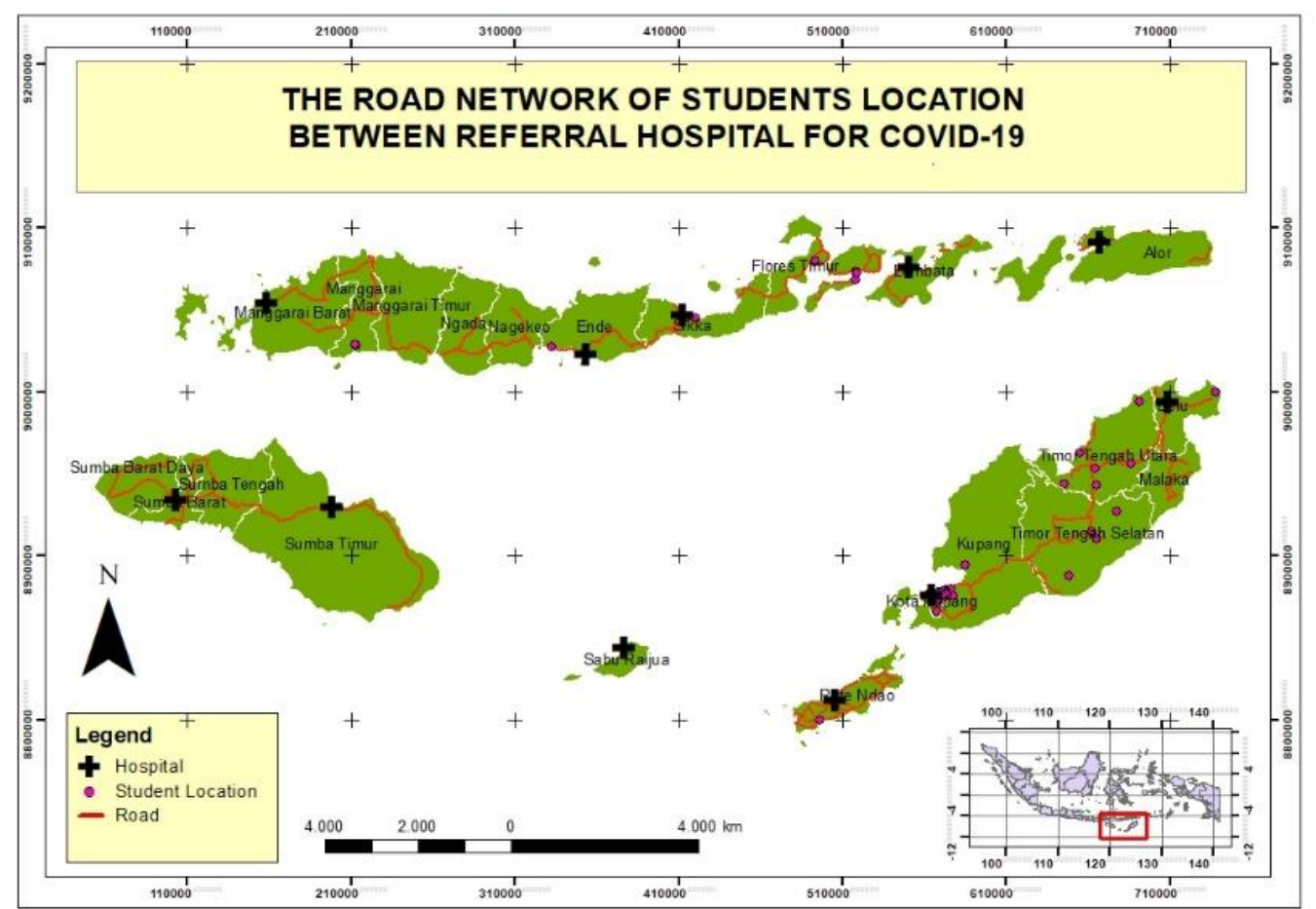

Figure 3. The Road Network

After that, analysis by using the OD layout then was made, the results are as Matrix Layer analysis was conducted. follows:

From the results of the analysis a map 


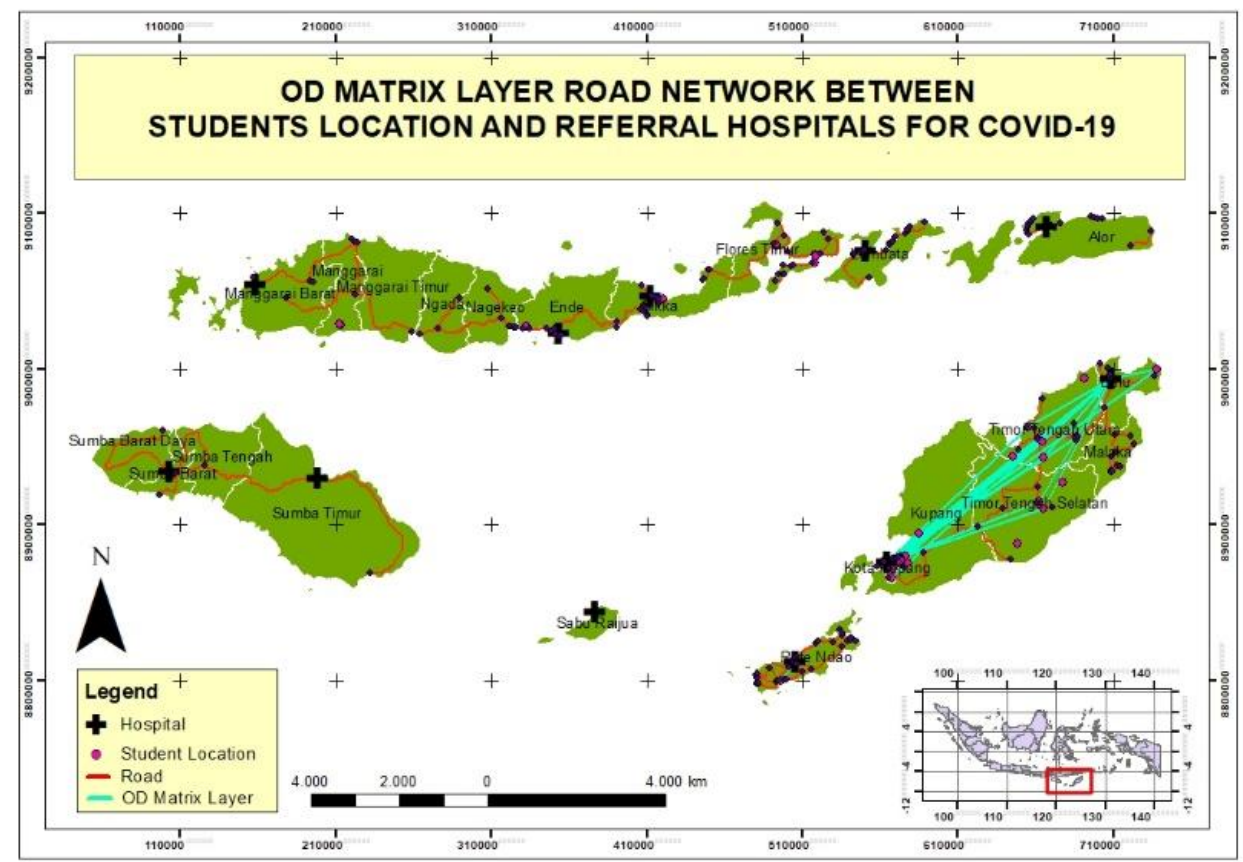

Figure 4. OD Matrix Layer

From the results of the OD Matrix Layer analysis, it was observed that not all students could reach the Covid-19 referral hospitals. The hospital rankings, ranked by the highest destinations could also be observed. The data were then arranged based on the results of the OD Matrix Layer analysis with the results below:

Table 3. Destination Rank

\begin{tabular}{l|c}
\hline \multicolumn{1}{c|}{ Name } & Destination Rank \\
\hline RSUD WZ. Yohanes Kupang & 1 \\
RSUD Komodo, Labuan Bajo & 2 \\
RSUD Ende & 3 \\
RSUD Lewoleba, Lembata & 4 \\
RSUD Alor & 5 \\
RSUD T.C. Hillers Maumere & 6 \\
RSUD Gabriel Manek, Belu & 7 \\
RSUD Ba'a Rote Ndao & 8 \\
RSUD Sabu Raijua & 9 \\
RSUD Waikabubak Sumba Barat & 10 \\
RSUD Umbu Rara Meha Waingapu & 11 \\
\hline Source: Data Analysis, 2020
\end{tabular}

Source: Data Analysis, 2020

In Table 3 observed that WZ. analysis, Not of all student locations could Yohanes Hospital in Kupang City was the reach the hospital location, as seen in the most accessible Covid-19 referral hospital Table 4. for students. From the OD Matrix Layer 
Table 4. Information of the Affordability Covid-19 Referral Hospitals to Student Locations.

\begin{tabular}{c|c|c}
\hline Information & Amount & Percentage (\%) \\
\hline Located & 59 & 67,82 \\
Unlocated & 28 & 38,18 \\
\hline
\end{tabular}

Source: Data analysis, 2020

Table 4 showed the results of the OD

Matrix Layer analysis, that there were 59 students or $67.82 \%$ whose locations could reach Covid-19 referral hospitals. Meanwhile, 28 students or $38.18 \%$ were unable to reach Covid-19 referral hospitals. This could threaten the student's condition if the student was then exposed to Covid-19 disease. From the analysis of OD Matrix Layer, the distance taken from a student to a referral hospital Covid-19 nearby could be observed as follows:

Table 5. The Distance of Student Location from the Nearest Covid-19

Reference Hospital

\begin{tabular}{c|c|c}
\hline Information & Amount & Percentage (\%) \\
\hline Less than $15 \mathrm{~km}$ & 35 & 40,22 \\
$15-30 \mathrm{~km}$ & 11 & 12,64 \\
More than $30 \mathrm{~km}$ & 13 & 14,96 \\
Unlocated & 28 & 32,18 \\
\hline
\end{tabular}

Source: Data analysis, 2020

Based on table 5, it could be seen that 35 students or $40.22 \%$ of their locations were less than $15 \mathrm{~km}$ from the location of the nearest Covid-19 referral hospital. With a distance of $15-30 \mathrm{~km}$, there were 11 students or $12.64 \%$, while more than $30 \mathrm{~km}, 13$ students or $14.96 \%$ were observed.

\section{Main Obstacle to Hospital Affordability}

The obstacle to hospital affordability based on the results of student survey are as follows:

Table 6. The Main Obstacle to Hospital Affordability

\begin{tabular}{l|c|c}
\hline \multicolumn{1}{c|}{ Information } & Amount & Percentage (\%) \\
\hline Facilities (ex:Transportation and road conditions) & 30 & 34,48 \\
geographic factors (ex : distance, slope and disaster-prone areas) & 57 & 65,52 \\
\hline
\end{tabular}

Source: Data analysis, 2020

Based on table 6, it could be seen the main obstacle to hospital affordability was geographic factor. East Nusa Tenggara province is in the form of an archipelago, 
although mean of transportation is available but the main transportation is ship. The Ship schedule which did not cover all the time (less than 24 hours ship schedule) could complicate the students in obtaining health services from the referral hospital.

\section{Solution}

Associated with the condition of East Nusa Tenggara province in the form of islands, the government could strengthen the role of community health centers such as puskesmas.

\section{CONCLUSIONS}

Not all student locations could reach the location of the Covid-19 referral hospital. Only 59 students or $67.82 \%$, which could be covered by the hospital. Meanwhile, 28 students or $32.18 \%$ could not reach the hospital. Based on the results of the OD Matrix Layer analysis it was known that WZ. Yohanes Hospital in Kupang City was the most reachable Covid-19 referral hospital from student locations. The government policy to make WZ. Yohanes Hospital as the main Covid19 referral hospital in East Nusa Tenggara Province was right. Amount of $40.22 \%$ of locations of the students were less than 15 $\mathrm{km}$ from the nearby location of a Covid-19 referral hospital. Geographic factor was the main obstacle to hospital affordability. Government could strengthen the role of community health centers such as "puskesmas" since it is the health service center that is closest to the people.

\section{E. REFERENCES}

Arifa, F. N. (2020). Tantangan Pelaksanaan Kebijakan Belajar Dari Rumah Dalam Masa Darurat Covid19. Info Singkat;Kajian Singkat Terhadap Isu Aktual Dan Strategis, XII(7/I), 6. http://berkas.dpr.go.id/puslit/files/in fo_singkat/InfoSingkat-XII-7-IP3DI-April-2020-1953.pdf

BNPB. (2020). Data sebaran. Gugus Tugas Percepatan Penanganan COVID-19, 1.

Dhawan, S. (2020). Online Learning: A Panacea in the Time of COVID-19 Crisis. Journal of Educational Technology Systems, 49(1), 5-22. https://doi.org/10.1177/0047239520 934018

Dryhurst, S., Schneider, C. R., Kerr, J., Freeman, A. L. J., Recchia, G., van der Bles, A. M., Spiegelhalter, D., \& van der Linden, S. (2020). Risk perceptions of COVID-19 around the world. Journal of Risk Research, 23(7-8), 994-1006. https://doi.org/10.1080/13669877.2 020.1758193

Emperador, D., Dittrich, S., Domen, J., Sra, H., A, V. D. B., \& Diagnostic, C. C.-. (2020). care or hospital outpatient settings has COVID-19 disease ( Review ). Cochrane. https://doi.org/10.1002/14651858.C D013665.www.cochranelibrary.co $\mathrm{m}$ 
Glass, C. A., Cash, J. C., \& Mullen, J. (2020). Coronavirus Disease (COVID-19). Family Practice Guidelines, October. https://doi.org/10.1891/9780826153 $425.0016 \mathrm{~b}$

Krishnakumari, P., van Lint, H., Djukic, T., \& Cats, O. (2020). A data driven method for OD matrix estimation. Transportation Research Part C: Emerging Technologies, 113, 38-56. https://doi.org/10.1016/j.trc.2019.05 .014

Lu, S., Wang, J., Xue, Z., \& Liu, X. (2016). Traffic Analysis and OD Travel Time Matrix Based on TwoFluid Model. Journal of Highway and Transportation Research and Development (English Edition), 10(3), 78-84. https://doi.org/10.1061/jhtrcq.00005 22

Maucourant, C., Filipovic, I., Ponzetta, A., Aleman, S., Cornillet, M., Hertwig, L., Strunz, B., Lentini, A., Reinius, B., Brownlie, D., Cuapio, A., Ask, E. H., Hull, R. M., HarounIzquierdo, A., Schaffer, M., Klingström, J., Folkesson, E., Buggert, M., Sandberg, J. K., ... Björkström, N. K. (2020). Natural killer cell immunotypes related to COVID-19 disease severity. Science Immunology, 5(50), 1-22. https://doi.org/10.1126/SCIIMMUN OL.ABD6832

Purwanto;, A., Asbari;, M., \& Santoso, P. B. (2019). Pengaruh Kompetensi, Motivasi, Kepemimpinan, Komitmen dan Budaya Kerja Sistem Manajemen Integrasi ISO 9001, ISO 14000 dan ISO 45001 pada Industri Otomotif. Jurnal Produktivitas, 6(2), 158-166. http://openjurnal.unmuhpnk.ac.id/in dex.php/jp/article/view/1798

Satgas Covid-19 NTT. (2020). DATA PRESS RELEASE HARI RABU Tabel Rumah Sakit Rujukan Covid19 di NTT. September, 2020.

Syuhada, K., Wibisono, A., Hakim, A., \& Addini, F. (2021). Covid-19 risk data during lockdown-like policy in Indonesia. Data in Brief, 35, 106801. https://doi.org/10.1016/j.dib.2021.1 06801

Watson, J. (n.d.). Interpreting a covid-19 test result. https://doi.org/10.1136/bmj.m1808 